\title{
The Influence Of The Working Shift Work And Stress On The Performance Of The Employes
}

\author{
Otfiyantoa" Abid Muhtarom "*Haris bashory ismail ${ }^{* *}$ Henny mahmudah ${ }^{* * * * *}$ \\ ***,***,**** Faculty of economics Islamic university lamongan, Otfiyanto@ gmail.com, Lamongan, Indonesia
}

\section{ARTICLE INFO}

Article history:

Received 10 April 2018

Received I Revised 01

Agustus 2018

Accepted 06 Agustus 2018

Keywords:

The Performance of employees, work Shift and Work stress.

\section{A B S T R A C T}

This research aims to find out the influence of partially or simultaneous as well as the most dominant variable about shift work and stress on the performance of the work of the employees employees in PT Jaya Brik Indonesia kemantren paciran lamongan. The research method used in this research is a quantitative method. Samples taken from the research as much as 75 respondents. Techniques data in this research using the questioner and the recording of the document and then in the analysis using multiple linear regression analysis with the help of the program SPSS 24 and eviews 9. The results of the study showed,(1) Shif work have positive and significant (t count 2,549>1,666 $t$ table) influence to the performance of employees and work stress have positive and significant ( $t$ count 3,294> 1,666 table) influance on the performance of the employees (2) Shift work and stress the work simultaneously have positive and significant ( $\mathrm{f}$ count 10,867 > $1.73 \mathrm{f}$ table) to the performance of employees. (3) the variables most affect the performance of the employees are working shift. The conclusion of the result is more stress and more high working shif rate frequence will improve the performance of employess.

Penelitian ini bertujuan untuk mengetahui pengaruh secara parsial atau simultan serta variabel yang paling dominan tentang shift kerja dan stres terhadap kinerja karyawan di PT Jaya Brik Indonesia kemantren paciran lamongan. Metode penelitian yang digunakan dalam penelitian ini adalah metode kuantitatif. Sampel diambil dari penelitian sebanyak 75 responden. Teknik pengumpulan data dalam penelitian ini menggunakan kuesioner dan pencatatan dokumen, kemudian di analisis menggunakan analisis regresi linier berganda dengan bantuan program SPSS 24 dan eviews 9. Hasil penelitian menunjukkan, (1) shift kerja memiliki nilai positif. dan signifikan (t hitung 2,549> 1,666 t tabel) pengaruh terhadap kinerja karyawan dan stres kerja memiliki positif dan signifikan (t hitung 3,294> 1,666 tabel) mempengaruhi kinerja karyawan (2) shift kerja dan stres kerja secara bersamaan memiliki nilai positif dan signifikan (f hitung 10,867> 1,73 f tabel) terhadap kinerja karyawan. (3) variabel yang paling mempengaruhi kinerja karyawan adalah shift kerja. Kesimpulan dari hasil penelitian adalah semakin stres dan semakin tinggi frekuensi shift kerja akan meningkatkan kinerja karyawan.

AKUISISI : Jurnal Akuntansi

Website : http://www.fe.ummetro.ac.id/ejournal/index.php/JA

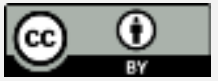

This is an open access article distributed under the terms of the Creative Commons Attribution 4.0 International License, which permits unrestricted use, distribution, and reproduction in any medium, provided the original work is properly cited.

E-mail address: Otfiyanto@gmail.com

Peer review under responsibility of Akuisisi : Accounting Journal. 2477-2984.

http://dx.doi.org/10.24217 


\section{INTRODUCTION}

The attention of Human Resources is very important in order to obtain the performance of the employees as expected in order to achieve the vision and mission of the organization. To create the condition above, an employee is required to have good performance. Now one of the things that affect is working conditions, working conditions is a working situation where workers do their work. Working Conditions have one indicator is working hours. In the work is divided into normal business hours and the system shift. In a company, usually imposed system shift. According to the Suma'mur (1994) shift work is a working time pattern is given on manpower to do something and usually divided to the work of the morning, the evening and night. In this regard several studies in the United States and in Europe shift work has impact on the performance of workers (Tayyari 1997) including error level of carefulness and the level of an accident. Better on the morning of the day on the night of the day so that in determining the shift work must be noted the combination of the type of work system shift and the type of workers. Wijaya (2006) stated that shift work can play an important role terhadappermasalahan on human beings problems; spread to sleep disorders, physical disorders and psychological and social disorders and family life. Shift can also affect some physical changes and the psychology of the human body are fatigue.

Some researchers study about shift work. Grandjen (1988) to identify the main factors that affect the health of the workers and tolerance shift work, such as the interaction between the individual, social conditions and work organization in drawing up a shift work. Some studies about the influence of the working shift toward the performance of workers and the factors that influence also has been done. Shift negative effect to the ability and performance of workers. Rouch, Wild, Ansiau, and Marquie (2005) stated that shift work in a long time will disrupt circadianrhythms that will cause disturbance on cognitive performance. Tomei et al (2006) stated that there is a tendency of increasing anxiety and aggressiveness on the end of a shift. In addition to shift work to minimize the performance degadation of the company must also consider stress work. Handoko (2008) stated that one of the factors that affect the performance of the employees is the level of stress employees. Work stress is a condition of tension experienced by employees or workers that can affect the emotional process of thinking and the condition of a man. Work stress can affect the ability of a person to face the work that will be able to inhibit the achievement of the expected performance and would harm the organization. Munandar (2008) stated that the stress experienced as a result of labor or other consequences of the process of the work which can be developed to make employment physical and mental hospital, so that they could not work more optimally.

Research on the influence of shift work and also to the performance of work stress have mixed results.Satrio (2015) "influence working shift work and stress on the performance of the sales person. The result says that the work and shift work stress negative effect. According to Takasenseran (2014). The influence of the work environment, communication and stress the work on the performance of the officers of the education and culture North Sulawesi province. The results stress the work have a positive effect on the performance of the employees. According to the razi dkk (2013) to examine the challenge the influence of work stress on the performance of the employees of community empowerment (BPM) the city of Banda Aceh. results work stress and psychological symptoms stress symptoms work behavior partially significant influence on the performance of the employees of the institution.

According to Astianto (2014) that research on the influence of stress and work load on the performance of the employees of the PDAM Surabaya. The results of the study showed that the working stress and work load simultaneously affect the significant impact on the performance of the employees, this proved with test $F$ which shows the value of the significance of 0,000 smaller than 0.05 . The results of the $t$ tests showed that the working stress and work load partially affect the performance of the 
employees. According to Mahardiani (2013) the influence of stress and work physical work environment of the employees performance outsorcing on PT Bank Central Java branch of the Coordinator and Branches region aiding City of Semarang. The results of research there is no influence of work stress variables have a negative effect on the performance of the employees of 2 percent, where the remaining influenced by other variables such as physical work environment.

Based on the Research gap that has been noted above, this research done to know how big the influence of shift work and stress on the performance of the work of the employees where in this required an in-depth study to find out through research activities with the title of "The Influence of Shift work and stress on the performance of the Work Employees (study on PT Jaya Brix Indonesia Kemantren Paciran Lamongan)

\section{METHOD}

The type of research that is used is the quantitative research. Quantitative research is research with how to collect data that is numeric then in a using the procedure statistics for getting an information behind the figure. This research use PT Jaya Brix as the location and all employee as population, from non random sampling quotes technique this research obtained 75 employee as the sample

Data used in this research is the primary and secondary data. The primary data in this research in the form of a questioner. While the secondary data in this research in the form of a document a document available in the company. For example about the information the history of the company, organizational structure and so on. While the technique of data collection is done by the researchers in this research in the form of a questioner and documentation.

According to Kroll (2010) shift work consists of two indicators , among others: 1).time breakdown shift the revolution of the working hours of the company quickly or slowly with the period of two days up to one month. 2). The succession of shift work is the succession of the desired working hours employees by changing the schedule work that has been determined by the company. Based on Robins (2006), stress work dapat measured with the indicator: 1) task demands, 2) the demands of the role of, 3) demands of inter-personal/colleagues working 4) organization structure 5) leadership. Now indikaor performance (wirawan, 2009): 1. The quality of the work 2. Working quantity 3. Timeliness 4. The same work 5. Independence 6 . The Initiative. This research use multiple regression analysis to find the influence of working shift and stress on performance. The test conducted from multiple regression analysis are $\mathrm{F}$ test and $\mathrm{T}$ test

\section{RESULTS AND DISCUSSION}

\subsection{Multiple Linear regression analysis}

This research uses multiple linear analysis methods because researchersan is using more than one variables, follows a summary of the results of the regresi in table 1 : 
The Table 1

Multiple Regression F Test and F Test

Dependent Variables: Performance

Method: This Squares

Date: 02/03/18 Time: 15:57

Sample: 175

Observations included: 75

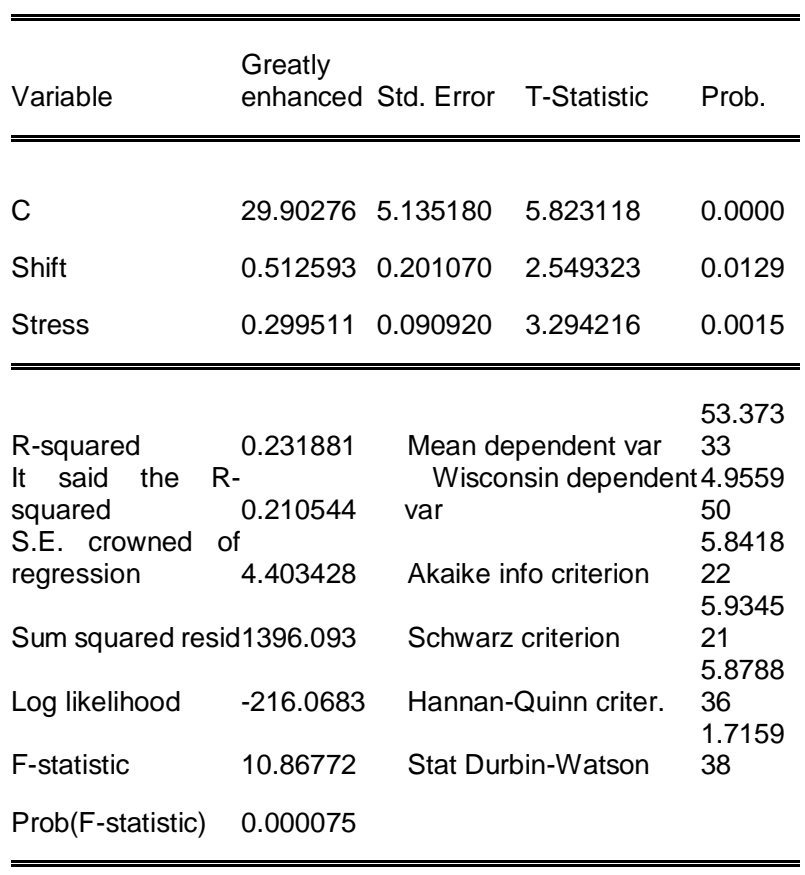

Source: Data processed eviews 9, 2018

Based on calculations using the program eviews 9, it is known that the regression equation model used is

$$
\mathrm{Y}=29.902+0,512 \mathrm{X} 1+0,299 \times 2
$$

The regression equation one (1) can be described as follows :

a. Shift work partially have positive and significant( $\mathrm{t}$ count 2,549 $>1,666 \mathrm{t}$ table) to the performance of employees and work stress also have positive and significant ( $\mathrm{t}$ count 3,294 $>1,666 \mathrm{t}$ table) to the performance of the employees of PT Jaya Brix Indonesia.

b. Working Shif and stress the work simultaneously have positive and significant (f count 10,867 $>2.73 \mathrm{f}$ table) to the performance of the employees of PT Jaya Brix Indonesia.

c. The variables shift work more influential dominant greatly enhanced X1 USD 0,512>0,299 greatly enhanced X2). against the performance of the employees of PT Jaya Brix Indonesia. 


\subsection{The influence of working shift work stress partially against the performance of the employees of PT Jaya Brix Indonesia Kemantren Paciran Lamongan.}

Based on the table one (1) above can be known that working shift have positive impact on the performance of the employees of PT Jaya Brix Indonesia Kemantren Paciran Lamongan (2,549). When the company PT Jayabrix Indonesia Kemantren Paciran Lamongan reproduction of work shift and likely performance of employees will be the better. This is because the more shift the performance of the employees will be more lightweight and make the pattern of life of the employees is not too heavy. So it can be conclude that the influence of the shif on the performance of the work employees have positive influence on employees performance Pt Jaya Brix Indonesia Kemantren Paciran Lamongan. This result is not in line with the research that has been done by pramono satrio (2015) which says that the shift work have a negative effect on the performance of the karyawan.

Furthermore assuming that stress work partially has negative effect on the performance of the employees of PT jaya brix indonesia kemantren paciran lamongan. From the regression data above it shows that work stress has a positive and significant impact on the performance of the karywan $\mathrm{Pt}$ Jaya Brix Indonesia Kemantren Paciran Lamongan (3,294). The employees of PT Jaya Brix Indonesia Kemantren Paciran Lamongan seems to have been familiar with stress the work so that even in the condition of stress their performance has increased. They are familiar with the work and the pressure of the pressure they face in the company. The first to go in the company does not require the expertise of difficult so that they have no other choice to not work there. Can deduce that work stress have a positive impact on the performance of the employees of PT Jaya brix Indonesia kemantren paciran lamongan. This result is not in line with the research pramono satrio (2015) said that stress the work have a negative effect on the performance of the employees. But in line with the research Takasenseran dkk (2014) said that stress the work have a positive effect on the performance of the employees.

\subsection{Influence and work shift work stress simultaneously against the performance of pt jaya brix karywan indonesia kemantren paciran lamongan}

From the regression above data can be explained that stress work and shift work together to actually have a positive effect on the performance of the employees of PT. Jaya Brix Indonesia Kemantren Paciran Lamongan (10,867). Shift work and also stress enough work can improve the performance of employees. The more shift then the better is the performance and the more stress the more good nor the performance of employees. Work stress here it can be said that the more stress or more pressure then employees will think about how they can make stress work become motivation to be more aggressive in work. So that its performance is increased. Thus it can be concluded that shift work and stress the work have a positive and significant impact on the performance of the employees of PT. Jaya Brix Indonesia Kemantren Paciran Lamongan. This is not in line with the research pramono satrio (2015) said that shift work and stress work together to have a negative effect on the performance of the employees. 


\subsection{Work shift have more dominant effect on the performance of the karywan Pt Jaya Brix Indonesia Kemantren Paciran Lamongan.}

From the regression data above shows that the shift work more dominant effect on the performance of the employees of PT. Jaya Brix Indonesia Kemantren Paciran Lamongan. in compare with stress work. Working shift work 0,299 0,512 and stress. Work Shift can cause many things did positive or negative. It all depends on how an employee can addressing the work shift. Can deduce that work shift the dominant influence on the performance of the employees of PT. Jaya Brix Indonesia Kemantren Paciran Lamongan. So the third hypothesis received. This result is not in line with the research pramono satrio (2015) who said that the dominant influential work stress on the performance of the employees.

\section{CONCLUSION}

From the result discussed above we find that performance of employees PT. Jaya Brix Indonesia Kemantren Paciran Lamongan will be better if they get more stress and high rate of working shift. The employees of PT Jaya Brix Indonesia Kemantren Paciran Lamongan seems to have been familiar with stress the work so that even in the condition of stress their performance has increased. They are familiar with the work and the pressure of the pressure they face in the company. The first to go in the company does not require the expertise of difficult so that they have no other choice to not work there. The more shift then the better is the performance and the more stress the more good nor the performance of employees. Work stress here it can be said that the more stress or more pressure then employees will think about how they can make stress work become motivation to be more aggressive in work. So that its performance is increased

\section{REFERENCES}

Ike Rachmawati Kusdyah. 2008. Human Resources Management. Yogyakarta : ANDI.

Suma'mur P.K,. (1984). The Company Hygene and Safety.Mold to 2. Jakarta: PT Gunung Agung

Riggio, E. R. (1996). Introduction to industrial organizational psychology. New York: Harper Collins Collage Publisher.

Kroll, Rainer. (2010). Evaluation Of The Effects Of Shift Work Assigment: A Survey Of Motivation In Police officials. Journal Proquest LLC New York

Nawawi, H.2006. The effectiveness of the leadership of the organization. The first print of Gadjah Mada University Press. Yogyakarta

Handoko, T.H 2011. Personnel management and Human Resources. The Second Edition. The Eighteenth print. BPFE publishers. Yogyakarta

Robins, Stepen P. (2006). Prioritising the organization. The Tenth Edition. Jakarta: PT Gramedia Group Index

Hasibuan, Malayu. 2009. Human Resources Management. Jakarta: Earth Characters

Anwar P..2002. The incentive and motivation to Other Countries. The eagle release. Jakarta.

Mangkunegara A. P.. Human Resources Management Teenagers Rosdakarya. Bandung. 
Wirawan, 2009, KinerjaManajemen Evaluation Human Resources, Jakarta : Salemba four. 